\title{
REMOVAL OF CATIONIC DYE (BASIC RED 18) FROM AQUEOUS SOLUTION USING NATURAL TURKISH CLAY
}

\author{
FIL B.A. ${ }^{1,2, *}$ \\ KARCIOGLU KARAKAS Z. ${ }^{1}$ \\ BONCUKCUOGLU R. ${ }^{1}$ \\ YILMAZ A.E. ${ }^{1}$
}

\author{
${ }^{1}$ Atatürk University, Faculty of Engineering, \\ Department of Environmental Engineering, \\ 25240, Erzurum, Turkey \\ ${ }^{2}$ Balıkesir University, Faculty of Engineering, \\ Department of Environmental Engineering \\ 10145, Balikesir, Turkey
}

Received: 02/08/12

Accepted: 08/10/13 *to whom all correspondence should be addressed: e-mail: baybarsalifil2@gmail.com

\begin{abstract}
In this study, the removal of a cationic dye, basic red 18, used in the textile industry with montmorillonite was investigated as a function of initial dye concentration, agitation speed, ionic strength, adsorbent dosage, $\mathrm{pH}$ and temperature. Adsorption process was attained to the equilibrium within 30 minutes. The adsorption capacity of basic red 18 increased with increasing ionic strength, initial dye concentration, $\mathrm{pH}$, agitation speed, and temperature, but decreased with increasing adsorbent dosage. The experimental data were analyzed by Langmuir, Freundlich, Temkin, Elovich and Dubinin-Radushkevich isotherms, and it was found that the isotherm data were reasonably correlated by Freundlich isotherm. Pseudo-first order, pseudo-second order, Elovich kinetic equations and intraparticle diffusion model were used to examine the experimental data of different initial conditions. It was found that the pseudo-second order kinetic equation described the data of dye adsorption onto montmorillonite very well. Furthermore, for the removal of basic red 18, a semiempirical model was established. Thermodynamic analysis was carried out for basic red 18 onto montmorillonite. It was found that the adsorption processes were endothermic in nature. The values of $\mathrm{E}_{a}, \Delta \mathrm{H}^{*}, \Delta \mathrm{S}^{*}$ and $\Delta \mathrm{G}^{*}$ at $293 \mathrm{~K}$ for basic red 18 adsorption on clay were calculated as $27.635 \mathrm{~kJ}$ $\mathrm{mol}^{-1}, 25.041 \mathrm{~kJ} \mathrm{~mol}^{-1},-0.090 \mathrm{~kJ} \mathrm{~mol}^{-1} \mathrm{~K}^{-1}$ and $51.412 \mathrm{~kJ} \mathrm{~mol}^{-1}$, respectively. The results indicated that montmorillonite could be employed as an alternative to commercial adsorbents in wastewater treatment for the removal of color and dyes.
\end{abstract}

KEYWORDS: Activation energy; Adsorption isotherm; Basic red 18; Freundlich isotherm; Montmorillonite; Pseudo-second-order kinetic.

\section{INTRODUCTION}

Environmental pollution control has been a concerned issue in many countries. The environmental issues surrounding the presence of color in effluent is continuing problem for dyestuff manufactures, dyers, finishers and water companies, because increasingly stringent color consent standard are being enforced by regulatory bodies to reduce the quality of color in effluent and water courses. One of the powerful treatment processes for the removal of dyes from water is adsorption. Adsorption techniques have been proven successful in removing colored organics (Kuleyin and Aydin, 2011; Kumar et al., 2011; Rafatullah et al., 2010). Adsorption is the separation of a substance from one phase accompanied by its accumulation or concentration at the surface of another. It is the process that takes place when a liquid or most commonly a gas known as the adsorbate accumulates on the surface of a solid adsorbent and forming a molecular film (Jain and Jayaram, 2010; Kumar et al., 2010).

Many adsorbents have been tested on the possibility to lower dye concentrations from aqueous solutions, such as activated carbon (Rodríguez et al., 2009), gallinaceous feathers (Sousa et al., 
2012), peat (Allen et al., 2004), chitin (Akkaya et al., 2007; Filipkowska et al., 2002), clay (Fil, 2007; Nandi et al., 2009), rice hulls (El-Maghraby and El Deeb, 2011), sludge ash (Weng and Pan, 2006), desert sand (Varlikli et al., 2009), water hyacinth roots (Saltabas et al., 2012), and rice husk ash (Mane et al., 2007; Verma and Mıshra, 2010). Activated carbon is the most popular adsorbent and has been used with great success (Ahmad et al., 2007; El-Halwany, 2010; Kilic et al., 2011; Nuithitikul et al., 2010; Yavuz and Aydin, 2006) and it's have high capacity for the adsorption of organic species. However, activated carbon suffers from high cost production and regeneration. Therefore, other adsorbents such as clays with higher surface areas are alternatives. Recent investigations have focused on the use of clays such as kaolinite (Dogan et al., 2009), montmorillonite (Elaziouti and Laouedj, 2011; Fil et al., 2012), sepiolite (Özdemir et al., 2006), diatomite (Al-Ghouti et al., 2009), illite (Pentrák et al., 2012), bentonite (Jiang et al., 2008) and perlite (Doğan and Alkan, 2003) to remove dyes.

Clay is a soil particle smaller than $0.002 \mathrm{~mm}$ or $2 \mu \mathrm{m}$, with high specific area which mainly influenced the soil colloidal properties as well as stability of soil structure. Besides, it has high stability in both wet and dry conditions and in soil texture class. While colloid is a particle, which may be a molecular aggregate, with a diameter of 0.1 to $0.001 \mu \mathrm{m}$, clay and soil organic matter are often called as soil colloids because they have particle sizes that are within, or approach colloidal dimensions. Clay minerals which are clay-sized hydrous aluminum silicates have a large interlayer space that can hold significant amounts of water and other substances. They encompassed of large surface area that allow swelling and shrinking. Montmorillonite is a very soft phyllosilicate mineral that typically forms in microscopic crystals, forming clay. Montmorillonite, a member of the smectite family, is 2:1 clay, meaning that it has 2 tetrahedral sheets sandwiching a central octahedral sheet. The particles are plate-shaped with an average diameter of approximately 1 micrometer. The particle thickness is extremely small $(\sim 1 \mathrm{~nm})$. It is the main constituent of the volcanic ash weathering product, bentonite. Montmorillonite's water content is variable and it increases greatly in volume when it absorbs water. Chemically it is hydrated sodium calcium aluminum magnesium silicate hydroxide $(\mathrm{Na}, \mathrm{Ca})_{0.33}(\mathrm{Al}$, $\mathrm{Mg}_{2}\left(\mathrm{Si}_{4} \mathrm{O}_{10}\right)(\mathrm{OH}) \cdot \mathrm{nH}_{2} \mathrm{O}$. Potassium, iron, and other cations are common substitutes; the exact ratio of cations varies with source (Fil, 2007; Rafatullah et al., 2010; Tsai et al., 2007).

This study was calculated to investigate the adsorption capacity of locally available low-cost adsorbents montmorillonite from Balikesir of Turkey, for basic red 18 (BR 18) dye removal from aqueous solutions. Therefore, the dynamical behaviors of adsorption were measured on the effect of initial dye concentration, agitation speed, ionic strength, adsorbent dosage, $\mathrm{pH}$ and temperature. Experimental data were performed for isotherm models such as Langmuir, Freundlich, Temkin, Elovich and Dubinin-Radushkevich. The adsorption rates were determined quantitatively and simulated by the Elovich, the pseudo-first-order and second-order models, and then adsorption mechanism was analyzed using intra-particle diffusion. Furthermore, thermodynamic activation parameters were also determined.

\section{MATERIAL AND METHOD}

Samples of montmorillonit were obtained from the Süd-Chemie (Balikesir, Turkey). Chemical composition and physical properties of montmorillonite were given in Table 1. Commercial quality cationic dye were obtained from Dyestar (Frankfurt, Germany) and used without any further purification. The structure of direct dye was given in Figure $1\left(390.89 \mathrm{~g} \mathrm{~mol}^{-1}\right.$ molecular weight and molecular formula $\mathrm{C}_{19} \mathrm{H}_{25} \mathrm{ClN}_{5} \mathrm{O}_{2}$ ). A stock solution of cationic dye was prepared in distilled water.<smiles>CCN(CC[N+](C)(C)C)c1ccc(N=Nc2ccc([N+](=O)[O-])cc2Cl)cc1</smiles>

Figure 1. The structure of basic red 18 
Table 1. Chemical composition of montmorillonite (a) and physicochemical properties of montmorillonite (b)

\begin{tabular}{|c|c|c|}
\hline \multirow{8}{*}{ (a) } & Component & Weight (\%) \\
\hline & $\mathrm{SiO}_{2}$ & 49.40 \\
\hline & $\mathrm{Al}_{2} \mathrm{O}_{3}$ & 19.70 \\
\hline & $\mathrm{MgO}$ & 0.27 \\
\hline & $\mathrm{CaO}$ & 1.50 \\
\hline & $\mathrm{Fe}_{2} \mathrm{O}_{3}$ & 0.30 \\
\hline & $\mathrm{Na}_{2} \mathrm{O}$ & 1.50 \\
\hline & $\mathrm{H}_{2} \mathrm{O}$ & 25.67 \\
\hline \multirow{7}{*}{ (b) } & Parameters & Value \\
\hline & Color & White \\
\hline & Density $\left(\mathrm{g} \mathrm{cm}^{-3}\right)$ & $2.3-3$ \\
\hline & Transparency & $\begin{array}{l}\text { Semi-transparent and } \\
\text { opaque }\end{array}$ \\
\hline & Brightness & Matt \\
\hline & Surface Area $\left(\mathrm{m}^{2} \mathrm{~g}^{-1}\right)$ & 95.36 \\
\hline & Reflective index & $1-2$ \\
\hline
\end{tabular}

The influences of variables including initial dye concentration, agitation speed, ionic strength, adsorbent dosage, $\mathrm{pH}$ and temperature and on the adsorptive removal of Basic Red 18 (BR 18) were investigated in batch mode. In each experimental run, $100 \mathrm{ml}$ of $\mathrm{BR} 18$ solution of different concentrations between $25-750 \mathrm{mg} \mathrm{L}^{-1}$ and varying amount montmorillonite were kept in a $250 \mathrm{ml}$ erlenmeyer flask. A constant agitation speeds using an Edmund Bühler incubator from $100 \mathrm{rpm}$ to $400 \mathrm{rpm}$ and at different temperatures form $293 \mathrm{~K}$ to $333 \mathrm{~K}$ was maintained for all the adsorption experiment. Ionic strength of aqueous solutions was adjusted with $\mathrm{NaCl}$ at examining ion intensity experiments. The solution $\mathrm{pH}$ was adjusted by addition of dilute aqueous solutions of $\mathrm{HCl}(0.01 \mathrm{M})$ or $\mathrm{NaOH}(0.01 \mathrm{M})$ using a WTW multi 340i pH-meter. Samples were taken at different contact times to determine the time required to reach equilibrium. After centrifugation at $10000 \mathrm{rpm}$, the absorbance of the supernatant was measured at $484 \mathrm{~nm}$ (Ghazi et al., 2003) using a Spekol-1100 UV-Vis spectrophotometer and then converted into concentration.

The adsorption equilibrium capacity of BR 18 was calculated using the following relationship:

$q_{e}=\frac{\left(C_{0}-C_{e}\right) \cdot V}{m}$

where $C_{0}\left(\mathrm{mg} \mathrm{L}^{-1}\right)$ and $C_{t}\left(\mathrm{mg} \mathrm{L}^{-1}\right)$ is the dye concentration at initial and after equilibrium time respectively. $V$ is the volume of the solution $(\mathrm{L})$ and $m$ is the mass $(\mathrm{g})$ of montmorillonite.

The adsorption capacity of BR 18 was calculated for kinetic studies by the following equation:

$q_{t}=\frac{\left(C_{0}-C_{t}\right) \cdot V}{m}$

where $C_{0}\left(\mathrm{mg} \mathrm{L}^{-1}\right)$ and $C_{t}\left(\mathrm{mg} \mathrm{L}^{-1}\right)$ is the dye concentration at initial and after time $\mathrm{t}$ respectively. $V$ is the volume of the solution $(\mathrm{L})$ and $m$ is the mass $(\mathrm{g})$ of montmorillonite.

\section{RESULT AND DISCUSSION}

\subsection{Adsorption isotherms}

The equilibrium adsorption of dyestuffs can be mathematically expressed in terms of adsorption isotherms. The parameters obtained from the different models provide important information on the adsorption mechanisms and the surface properties and affinities of the adsorbent. The most widely accepted surface adsorption models for single-solute systems are the Langmuir and Freundlich models. The correlation with the amount of adsorption and the liquid-phase concentration was tested with the Langmuir, Freundlich, Elovich, Temkin and Dubinin-Radushkevich (D-R) isotherm equations were given in the Table 2 (Dubinin and Radushkevich, 1947; Elovich and Larionov, 1962; Freundlich, 1906; Langmuir, 1918; Temkin, 1941). Linear regression is frequently used to determine the best-fitting isotherm, and the applicability of isotherm equations is compared by judging the correlation coefficients. 
Table 2. Isotherm models equations (a) and kinetic models equations (b)

\begin{tabular}{|c|c|c|c|c|}
\hline & Isotherm & Mathematical equations & Eq. & References \\
\hline \multirow{6}{*}{ (a) } & Langmuir & $q_{e}=\left(q_{m} K_{L} C_{e}\right) /\left(1+K_{L} C_{e}\right)$ & (3) & (Langmuir, 1918) \\
\hline & Freundlich & $q_{e}=K_{F} C_{e}^{1 / n}$ & (4) & (Freundlich, 1906) \\
\hline & Elovich & $q_{e} / q_{m}=K_{E} C_{e} \exp \left(-q_{e} / q_{m}\right)$ & (5) & $\begin{array}{l}\text { (Elovich and Larionov, } \\
\text { 1962) }\end{array}$ \\
\hline & Temkin & $q_{e}=(R T / b) \ln \left(K_{T} C_{e}\right)$ & (6) & (Temkin, 1941) \\
\hline & Dubinin-Radushkevich & $q_{e}=q_{m} \exp \left[-B\left(R T \ln \left(1+1 / C_{e}\right)^{2}\right)\right]$ & (7) & $\begin{array}{l}\text { (Dubinin and } \\
\text { Radushkevich, 1947) }\end{array}$ \\
\hline & Kinetic model & Mathematical equations & Eq. & References \\
\hline \multirow{3}{*}{ (b) } & $\begin{array}{l}\text { pseudo-first order rate } \\
\text { model } \\
\text { pseudo-second-order rate } \\
\text { model }\end{array}$ & $\begin{array}{l}\ln \left(q_{e}-q_{t}\right)=\ln q_{e}-k_{1} t \\
t / q_{t}=\left[1 / k_{2} q_{e}^{2}\right]+\left(1 / q_{e}\right) t\end{array}$ & $\begin{array}{l}(8) \\
(9)\end{array}$ & $\begin{array}{l}\text { (Ho and McKay, 1998) } \\
\text { (Ho et al., 1996) }\end{array}$ \\
\hline & Elovich model & $q_{t}=\beta \ln (\alpha \beta)+\beta \ln t$ & (10) & (McKay et al., 1999) \\
\hline & Intra Particle model & $q_{t}=k_{d i f} t^{1 / 2}+C$ & (11) & $\begin{array}{l}\text { (Furusawa and Smith, } \\
\text { 1974) }\end{array}$ \\
\hline
\end{tabular}

Correlation coefficients and constants of the isotherm models were given in the Table 3 . As could be seen from table and Fig. 2, experimental results with the best fit Freundlich isotherm (lyim and Güçlü, 2009). The capacity of the adsorption isotherm is fundamental, and plays an important role in the determination of the maximum capacity of adsorption. As could be seen from experimental results maximum adsorption capacity of BR 18 dye onto montmorillonite clay was calculated as $530.645 \mathrm{mg} \mathrm{g}^{-1}$ at $\mathrm{pH}: 4.0,293 \mathrm{~K}$ temperature, $300 \mathrm{rpm}$ agitation speed, $0.5 \mathrm{~g} \mathrm{~L}^{-1}$ adsorbent dosage and $0 \mathrm{~mol} \mathrm{~L}^{-1} \mathrm{NaCl}$ ionic strength (Fig. 2). Comparison of the adsorption capacity of cationic dyes onto adsorbents such as clay species was shown Table 4 (Guiza et al., 2004; lyim and Güçlü, 2009; Jiang et al., 2008; Karim et al., 2009; Karim et al., 2010; Tahir and Rauf, 2006; Wang and Zhang, 2011).

Table 3. Isotherm constants for basic red 18 adsorption onto montmorillonite

\begin{tabular}{cccc}
\hline \multicolumn{2}{c}{ Langmuir isotherm } & \multicolumn{2}{c}{ Freundlich isotherm } \\
\hline $\mathrm{K}_{\mathrm{L}}$ & 0.0614 & $\mathrm{~K}_{\mathrm{F}}$ & 79.8475 \\
$\mathrm{q}_{\mathrm{m}}$ & 529.6330 & $\mathrm{n}$ & 3.3965 \\
$\mathrm{R}^{2}$ & 0.970 & $\mathrm{R}^{2}$ & 0.995 \\
\hline \multicolumn{2}{c}{ Temkin isotherm } & \multicolumn{2}{c}{ Elovich isotherm } \\
\hline $\mathrm{K}_{\mathrm{T}}$ & 4.5766 & $\mathrm{q}_{\mathrm{m}}$ & 93.6938 \\
$\mathrm{~b}$ & 42.3344 & $\mathrm{~K}_{\mathrm{E}}$ & \\
$\mathrm{R}^{2}$ & 0.879 & $\mathrm{R}^{2}$ & \\
\hline Dubinin-Radushkevich isotherm & & \\
\hline $\mathrm{q}_{\mathrm{m}}$ & 262.3415 & & \\
$\mathrm{~B}$ & $7.806 .10^{-08}$ & & \\
$\mathrm{R}^{2}$ & 0.572 & & \\
\hline
\end{tabular}

\subsection{Adsorption Kinetics}

Several steps can be used to examine the controlling mechanism of adsorption process such as chemical reaction, diffusion control and mass transfer; kinetic models are used to test experimental data from the adsorption of BR 18 onto montmorillonite clay. The kinetics of dyes adsorption onto montmorillonite is required for selecting optimum operating conditions for the full-scale batch process. The kinetic parameters, which are helpful for the prediction of adsorption rate, give important information for designing and modeling the adsorption processes. Thus, the kinetics of BR 18 adsorption onto montmorillonite were analyzed using pseudo-first-order, pseudo-second-order, Elovich and intraparticle diffusion kinetic models were given in Table 2 (Furusawa and Smith, 1974; Ho and McKay, 1998; Ho et al., 1996; McKay et al., 1999). The conformity between experimental 


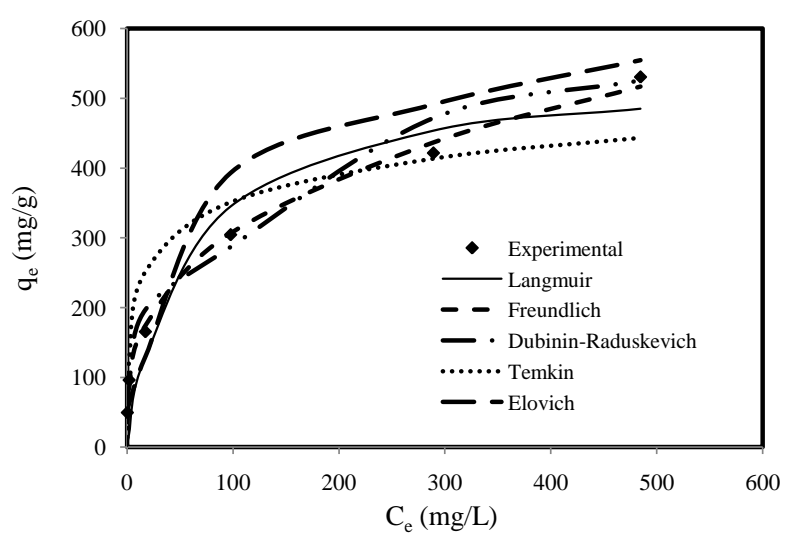

Figure 2. Comparison of isotherm models on dye adsorption on montmorillonite

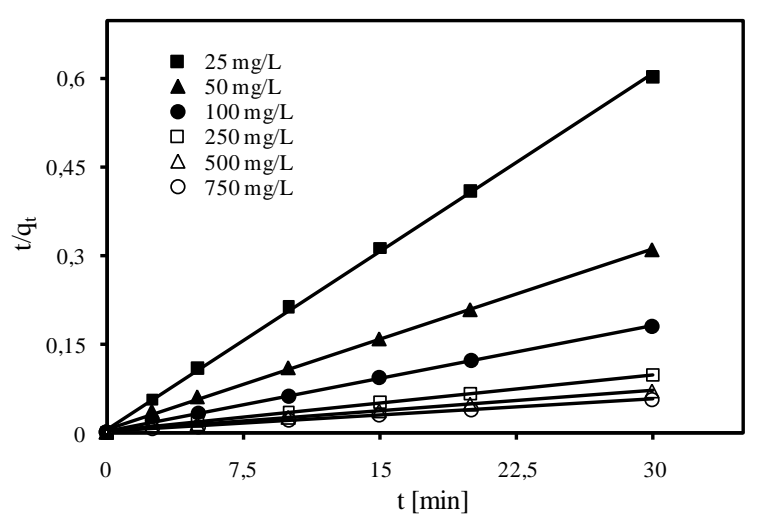

Figure 3. Pseudo-second-order kinetic models on dye adsorption on montmorillonite

Table 4. Comparison of the adsorption capacity of cationic dyes onto adsorbents such as clay

\begin{tabular}{|c|c|c|c|}
\hline Adsorbent & Adsorban & $\begin{array}{l}\text { Maximum adsorption } \\
\text { capacity }\left(\mathrm{mg} \mathrm{g}^{-1}\right)\end{array}$ & Ref. \\
\hline Bentonite & Malachite Green & 7.716 & (Tahir and Rauf, 2006) \\
\hline $\begin{array}{l}\text { Na-Bentonite And } \\
\text { Ca-Bentonite }\end{array}$ & Basic Violet 14 & 147.9 and 100 & (Jiang et al., 2008) \\
\hline $\begin{array}{l}\text { Crude And Purified } \\
\text { Clay }\end{array}$ & Methylene Blue & 50 and 68,5 & (Karim et al., 2010) \\
\hline Natural Clay & $\begin{array}{l}\text { Nile Blue And Brilliant } \\
\text { Cresyl Blue }\end{array}$ & 25 and 42 & (Iyim and Güçlü, 2009) \\
\hline $\begin{array}{l}\text { Cu(II)-Loaded } \\
\text { Montmorillonite }\end{array}$ & Crystal Violet & 114.3 & (Wang and Zhang, 2011) \\
\hline Moroccan Clay & Basic Red 46 & 54 & (Karim et al., 2009) \\
\hline Natural Clay & $\begin{array}{l}\text { Neutral Red, Methyl } \\
\text { Violet, Methyl Green And } \\
\text { Methylene Blue, }\end{array}$ & $\begin{array}{c}567,526,427 \text { and } \\
300\end{array}$ & (Guiza et al., 2004) \\
\hline Montmorillonite & Basic Red 18 & 530.645 & In this study \\
\hline
\end{tabular}

data and the model-predicted values was expressed by the correlation coefficients $\left(R^{2}\right.$, values close or equal to 1). The relatively higher value is the more applicable model to the kinetics of dye adsorption onto clay. The linear plots of $t / q_{t}$ versus $t$ showed good agreement between experimental and calculated $q_{e}$ values at all experimental conditions than other models (Table 5). The correlation coefficients for the second-order kinetic model were greater than 0.995 which led to believe that the pseudo-second-order kinetic model provided good correlation for the adsorption of BR 18 onto montmorillonite (Dogan et al., 2007; Doğan et al., 2006; Fil and Özmetin, 2012). The obtained results were shown for initial BR 18 concentrations in Figure 3.

Besides for adsorption on the outer surface of adsorbent, there is also a possibility of transport of adsorbate dye from the solution to the pores of the adsorbent due to vigorous agitation during the adsorption process. It is probably reasonable to assume that the rate is not limited by mass transfer of BR 18 from the aqueous solution liquid to the clay particle external surface. One might then base that the rate limiting step may be film or intra-particle diffusion. The most commonly used technique for identifying the mechanism involved in the adsorption process is by using intra-particle diffusion model (Wu et al., 2009) was given by Table 2. The $R^{2}$ values were given in Table 5 were close to unity indicating the application of this model. This may confirm that the rate-limiting step is the intraparticle diffusion process. The linearity of the plots demonstrated that intraparticle diffusion played a significant role in the uptake of the adsorbate by adsorbent. 


\subsection{Effect of initial adsorbate concentration on adsorption process}

The influence of the initial concentration of basic red $18\left(25-750 \mathrm{mg} \mathrm{L}^{-1}\right)$ on the adsorption rate using montmorillonite was studied. The experiments were carried out at $0.5 \mathrm{~g} \mathrm{~L}^{-1}$ adsorbent dose, at 300 rpm agitation speed, at $0 \mathrm{~mol} \mathrm{~L}^{-1} \mathrm{NaCl}$ concentration, at $293 \mathrm{~K}$ temperature and at $\mathrm{pH}: 4.0$ for $30 \mathrm{~min}$ (Fig. 4). The percent adsorption decreased with increase in initial dye concentration, but the actual amount of dye adsorbed per unit mass of adsorbent increased with increase in dye concentration in the test solution for different concentrations $\left(25-750 \mathrm{mg} \mathrm{L}^{-1}\right)$ at the same time $(\mathrm{min})$. The increase in adsorption with the increase in BR 18 concentration is due to the driving force that initial concentration provides to overcome the mass transfer resistance between the aqueous and solid phases. The adsorption rate was high at early adsorption period due to availability of large number of vacant site which increased the concentration gradient between the adsorbate in the solution and adsorbate on the adsorbent surface (Zohra et al., 2008). Similar results were observed in the literature (Karadag et al., 2007; Unuabonah et al., 2008).

\subsection{Effect of agitation speed on adsorption process}

Adsorption studies were carried out with an orbital incubator at $\mathrm{pH}: 4.0$, which is initial $\mathrm{pH}$ of the dyed solution. Basic red 18 dye solution was $100 \mathrm{mg} \mathrm{L}^{-1}$. The agitation speed varied from 100 to 400 rpm. The adsorption efficiency increased because of increasing kinetic energy between the dye molecules and the montmorillonite particles (Fig. 5). Thus, the adsorption efficiency increased with increasing agitation speed and the dye removal efficiency was maximal at $400 \mathrm{rpm}$. The effect of agitation rate onto the montmorillonite was shown in Fig. 5. The BR 18 dye adsorbate on per gram of the montmorillonite increased because of increasing kinetic energy between the dye molecules and the montmorillonite particles. The dye adsorption capacities for different agitation rates $(100,200$, 300 and $400 \mathrm{rpm}$ ) were obtained as $140.933,153.634,165.586$ and $172.564 \mathrm{mg} \mathrm{g}^{-1}$, respectively (Nandi et al., 2009).

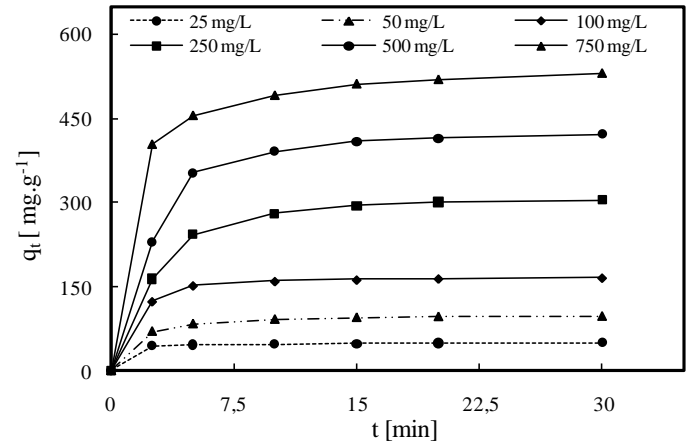

Figure 4. Effect of initial dye concentration on dye adsorption on montmorillonite

(Conditions: agitation speed $300 \mathrm{rpm}$, adsorbent dosage $0.5 \mathrm{~g} \mathrm{~L}^{-1}$, temperature $293 \mathrm{~K}$, ionic strength $0 \mathrm{~mol} \mathrm{~L}^{-1} \mathrm{NaCl}$, solution $\mathrm{pH}: 4.0$ )

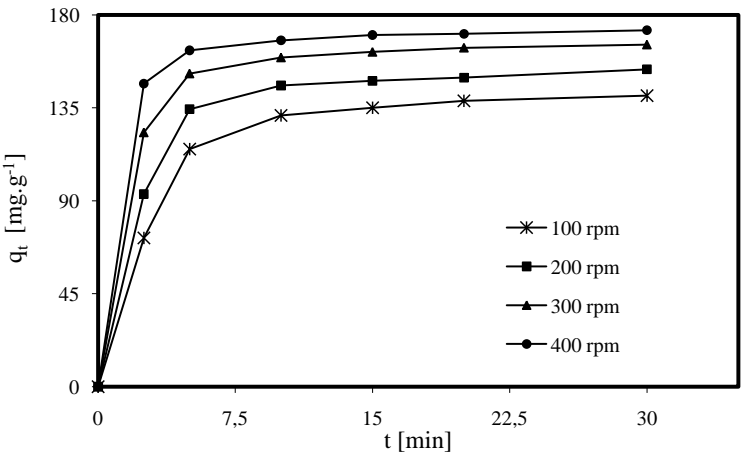

Figure 5. Effect of agitation speed on dye adsorption on montmorillonite

(Conditions: initial dye concentration $100 \mathrm{mg} \mathrm{L}^{-1}$, adsorbent dosage $0.5 \mathrm{~g} \mathrm{~L}^{-1}$, temperature $293 \mathrm{~K}$, ionic strength: $0 \mathrm{~mol} \mathrm{~L}^{-1} \mathrm{NaCl}$, solution $\mathrm{pH}: 4.0$ )

\subsection{Effect of ionic strength on adsorption process}

As shown in Fig. 6, adsorption of BR 18 on montmorillonite increased upon addition of small quantities of salt. The effect of ionic strength on dye adsorption onto montmorillonite surface was studied on $0 \mathrm{M}, 1 \times 10^{-1} \mathrm{M}, 1 \times 10^{-2} \mathrm{M}$, and $1 \times 10^{-3} \mathrm{M} \mathrm{NaCl}$ solutions at $\mathrm{pH}$ : $4.0,300 \mathrm{rpm}$ agitation speed, $293 \mathrm{~K}$ temperature, $0.5 \mathrm{~g} \mathrm{~L}^{-1}$ adsorbent dosage and $100 \mathrm{mg} \mathrm{L}^{-1}$ initial adsorbate concentration. Theoretically, when the electrostatic forces between the adsorbent surface and adsorbate ions were attractive, as in this system, an increase in ionic strength will decrease the adsorption capacity. Conversely, when the electrostatic attraction is repulsive, an increase in ionic strength will increase adsorption (Fil and Özmetin, 2012; Wang and Zhang, 2011). The experimental data from this study did not follow this convention, as the adsorption of negatively charged dye molecules on positively charged montmorillonite increased with $\mathrm{NaCl}$ addition. The increase in dye removal after $\mathrm{NaCl}$ addition can be attributed to an increase in resolution of $\mathrm{BR} 18$ in solution. 
Table 5. Kinetic constants for basic red 18 adsorption onto montmorillonite

\begin{tabular}{|c|c|c|c|c|c|c|c|c|c|c|c|}
\hline \multicolumn{6}{|c|}{ Parameters } & \multicolumn{6}{|c|}{ Kinetic models } \\
\hline \multirow{2}{*}{ 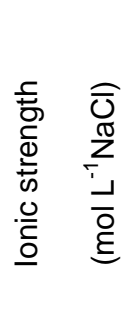 } & \multirow{2}{*}{ 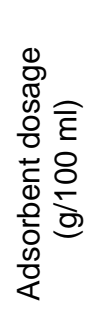 } & \multirow{2}{*}{ 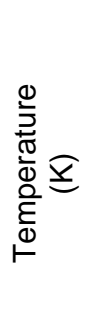 } & \multirow{2}{*}{ 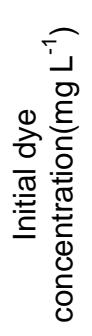 } & \multirow[b]{2}{*}{$\frac{T}{2}$} & \multirow{2}{*}{ 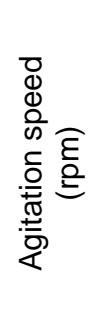 } & \multicolumn{3}{|c|}{ Pseudo - second - order } & \multirow{2}{*}{$\begin{array}{c}\begin{array}{c}\text { Pseudo - first - } \\
\text { order }\end{array} \\
\mathrm{R}^{2}\end{array}$} & \multirow{2}{*}{$\begin{array}{c}\text { The Elovich } \\
\text { Equation } \\
\mathrm{R}^{2}\end{array}$} & \multirow{2}{*}{$\begin{array}{c}\text { Intra-particle } \\
\mathrm{R}^{2}\end{array}$} \\
\hline & & & & & & $\begin{array}{c}\mathrm{h}=\mathrm{k}_{2} \times \mathrm{q}_{\mathrm{e}}{ }^{2} \\
\mathrm{mg} \mathrm{g}^{-1} \mathrm{~min}^{-1}\end{array}$ & $\begin{array}{c}\mathrm{k}_{2} \times 10^{3} \\
\mathrm{~g} \mathrm{mg}^{-1} \min ^{-1}\end{array}$ & $\mathrm{R}^{2}$ & & & \\
\hline 0 & 0.050 & 293 & 100 & 4.0 & 300 & 346.021 & 0.012279 & 0.999 & 0.914 & 0.830 & 0.857 \\
\hline 0 & 0.050 & 303 & 100 & 4.0 & 300 & 471.921 & 0.015231 & 1.000 & 0.886 & 0.802 & 0.821 \\
\hline 0 & 0.050 & 313 & 100 & 4.0 & 300 & 612.745 & 0.018027 & 1.000 & 0.793 & 0.813 & 0.805 \\
\hline 0 & 0.050 & 323 & 100 & 4.0 & 300 & 929.368 & 0.026116 & 1.000 & 0.793 & 0.776 & 0.810 \\
\hline 0 & 0.050 & 333 & 100 & 4.0 & 300 & 1997.204 & 0.052535 & 1.000 & 0.770 & 0.627 & 0.646 \\
\hline 0 & 0.050 & 293 & 25 & 4.0 & 300 & 146.007 & 0.058929 & 1.000 & 0.744 & 0.993 & 0.878 \\
\hline 0 & 0.050 & 293 & 50 & 4.0 & 300 & 152.625 & 0.015836 & 0.999 & 0.973 & 0.922 & 0.704 \\
\hline 0 & 0.050 & 293 & 100 & 4.0 & 300 & 346.021 & 0.012279 & 0.999 & 0.914 & 0.830 & 0.857 \\
\hline 0 & 0.050 & 293 & 250 & 4.0 & 300 & 256.345 & 0.002553 & 0.996 & 0.986 & 0.894 & 0.896 \\
\hline 0 & 0.050 & 293 & 500 & 4.0 & 300 & 396.825 & 0.002085 & 0.996 & 0.954 & 0.847 & 0.872 \\
\hline 0 & 0.050 & 293 & 750 & 4.0 & 300 & 825.764 & 0.002857 & 0.999 & 0.913 & 0.972 & 0.885 \\
\hline 0 & 0.025 & 293 & 100 & 4.0 & 300 & 342.231 & 0.008396 & 0.999 & 0.934 & 0.896 & 0.889 \\
\hline 0 & 0.050 & 293 & 100 & 4.0 & 300 & 346.021 & 0.012279 & 0.999 & 0.914 & 0.830 & 0.857 \\
\hline 0 & 0.075 & 293 & 100 & 4.0 & 300 & 337.952 & 0.021113 & 1.000 & 0.882 & 0.824 & 0.642 \\
\hline 0 & 0.100 & 293 & 100 & 4.0 & 300 & 277.085 & 0.027836 & 1.000 & 0.864 & 0.820 & 0.444 \\
\hline 0 & 0.050 & 293 & 100 & 4.0 & 100 & 117.261 & 0.005464 & 0.995 & 0.958 & 0.853 & 0.904 \\
\hline 0 & 0.050 & 293 & 100 & 4.0 & 200 & 187.371 & 0.007603 & 0.998 & 0.871 & 0.812 & 0.879 \\
\hline 0 & 0.050 & 293 & 100 & 4.0 & 300 & 346.021 & 0.012279 & 0.999 & 0.914 & 0.830 & 0.857 \\
\hline 0 & 0.050 & 293 & 100 & 4.0 & 400 & 616.143 & 0.047260 & 1.000 & 0.837 & 0.864 & 0.780 \\
\hline 0 & 0.050 & 293 & 100 & 4.0 & 300 & 346.021 & 0.012279 & 0.999 & 0.914 & 0.830 & 0.693 \\
\hline 0 & 0.050 & 293 & 100 & 6.0 & 300 & 444.642 & 0.014174 & 1.000 & 0.919 & 0.877 & 0.835 \\
\hline 0 & 0.050 & 293 & 100 & 8.0 & 300 & 438.596 & 0.012418 & 1.000 & 0.764 & 0.918 & 0.802 \\
\hline 0 & 0.050 & 293 & 100 & 10.0 & 300 & 400.320 & 0.010465 & 0.999 & 0.906 & 0.897 & 0.749 \\
\hline 0 & 0.050 & 293 & 100 & 4.0 & 300 & 346.021 & 0.012279 & 0.999 & 0.914 & 0.830 & 0.857 \\
\hline 0.001 & 0.050 & 293 & 100 & 4.0 & 300 & 389.712 & 0.013119 & 0.999 & 0.895 & 0.833 & 0.901 \\
\hline 0.010 & 0.050 & 293 & 100 & 4.0 & 300 & 473.709 & 0.015154 & 1.000 & 0.917 & 0.846 & 0.916 \\
\hline 0.100 & 0.050 & 293 & 100 & 4.0 & 300 & 481.464 & 0.012543 & 1.000 & 0.868 & 0.837 & 0.916 \\
\hline
\end{tabular}




\subsection{Effect of adsorbent dosage on adsorption process}

The effect of adsorbent amount on the uptake of the dye was measured for dye concentration 100 $\mathrm{mg} \mathrm{L}^{-1}$, and different quantity of clay $\left(0.25,0.50,0.75\right.$ and $\left.1.00 \mathrm{~g} \mathrm{~L}^{-1}\right)$ at $\mathrm{pH} 4,300 \mathrm{rpm}$ agitation speed and $293 \mathrm{~K}$ temperature (Figure 7 ). In general, it was found that by increasing the amount of the adsorbent the adsorption rate increased. This increase was most significant when the amount of adsorbent increased from $\left(0.25-1.00 \mathrm{~g} \mathrm{~L}^{-1}\right)$. Maximum dye removal was achieved within 30 minutes after which a decrease in BR 18 concentration was negligible. Increase in dye removal percentage with adsorbent dose can be attributed to increased adsorbent surface area and availability of more adsorption sites. But, when was increased adsorbent dosage from $0.25 \mathrm{~g} \mathrm{~L}^{-1}$ to $1.00 \mathrm{~g} \mathrm{~L}^{-1}$, adsorption capacity decreased from $198.701 \mathrm{mg} \mathrm{g}^{-1}$ to $98.868 \mathrm{mg} \mathrm{g}^{-1}$. This may be attributed to the availability of more sorption sites due to higher amount of the sorbent. At higher montmorillonite to solute ratios, there is a very fast sorption onto the sorbent surface that produces a lower solute concentration in the solution compared to the sorbent to solute concentration ratio is lower (Vimonses et al., 2009). At the beginning of the process the rate of dye removal by the clay was fast during the first $10 \mathrm{~min}$ and then decreased gradually.

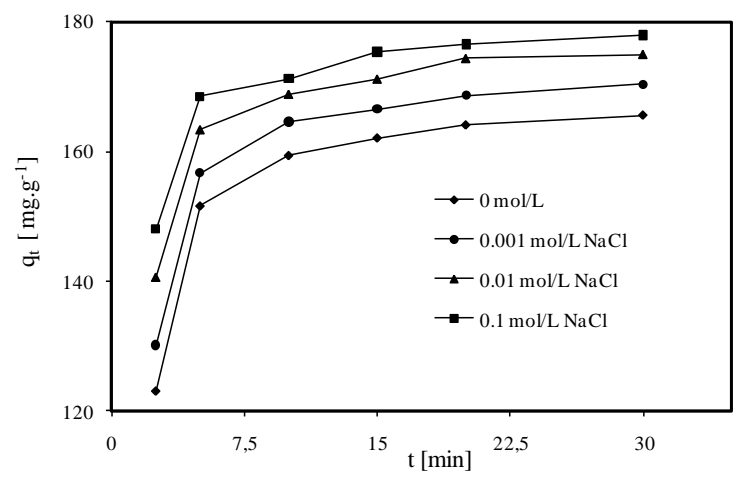

Figure 6. Effect of ionic strength on dye adsorption on montmorillonite

(Conditions: initial dye concentration $100 \mathrm{mg} \mathrm{L}^{-1}$ adsorbent dosage $0.5 \mathrm{~g} \mathrm{~L}^{-1}$, temperature $293 \mathrm{~K}$, agitation speed $300 \mathrm{rpm}$, solution $\mathrm{pH}: 4.0$ )

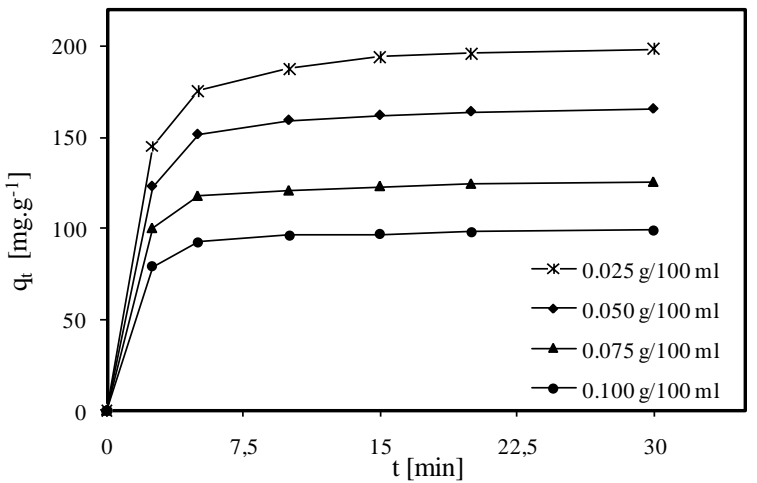

Figure 7. Effect of adsorbent dosage on dye adsorption on montmorillonite

(Conditions: initial dye concentration $100 \mathrm{mg} \mathrm{L}^{-1}$, agitation speed $300 \mathrm{rpm}$, temperature $293 \mathrm{~K}$, ionic strength $0 \mathrm{~mol} \mathrm{~L}^{-1} \mathrm{NaCl}$, solution $\mathrm{pH}: 4.0$ )

\subsection{Effect of initial solution $\mathrm{pH}$ on adsorption process}

The $\mathrm{pH}$ value of the solution is an important parameter for the adsorption processes, and the initial $\mathrm{pH}$ value of the solution has significant influence compared to than the final $\mathrm{pH}$. To study the effect of $\mathrm{pH}$ on BR 18 adsorption, the experiments were carried out at $100 \mathrm{mg} \mathrm{L}^{-1}$ initial dye concentration with $0.5 \mathrm{~g} \mathrm{~L}^{-1}$ adsorbent dosage at $293 \mathrm{~K}$ and $300 \mathrm{rpm}$ agitation speed. In general, initial pH value may enhance or depress the uptake. This is attributed to the charge of the adsorbent surface with the change in $\mathrm{pH}$ value. Figure 8 showed the relationship between the $\mathrm{pH}$ value and the adsorption capacity of BR 18. It could be seen from the figure that as the solution $\mathrm{pH}$ increased, the adsorption capacity increased. Increasing solution $\mathrm{pH}$ increases the number of hydroxyl groups thus, increases the number of negatively charge sites and enlarges the attraction between dye and adsorbent surface, (Karim et al., 2009). Generally, the net positive charge decreases with increasing pH value lead in the decrease in the repulsion between the adsorbent surface and the dye thus, improving the adsorption capacity.

\subsection{Effect of solution temperature on adsorption process}

The effect of temperature on the removal of BR 18 dye was investigated effect of solution temperature $(293,303,313,323$ and 333$) \mathrm{K}$ at $\mathrm{pH}: 4.0,300 \mathrm{rpm}$ agitation speed, $0.5 \mathrm{mg} \mathrm{L}^{-1}$ adsorbent dosage, $0 \mathrm{~mol} \mathrm{~L}^{-1} \mathrm{NaCl}$ salt concentration and $100 \mathrm{mg} \mathrm{L}^{-1}$ initial adsorbate concentration. The results were graphed in Fig. 9. From this figure, it has been observed when increased solution temperature from $293 \mathrm{~K}$ to $333 \mathrm{~K}$, adsorption capacity of BR 18 onto montmorillonite increased from $165.586 \mathrm{mg} \mathrm{g}^{-1}$ to $194.311 \mathrm{mg} \mathrm{g}^{-1}$. The kinetic energy between the dye molecules and the montmorillonite particles increased with increasing the temperature of the solution. The collision 
frequency between adsorbent and the dye molecules increased then the dye molecules electrostatically adsorbed onto the surface of the adsorbent particles (Weng and Pan, 2007).

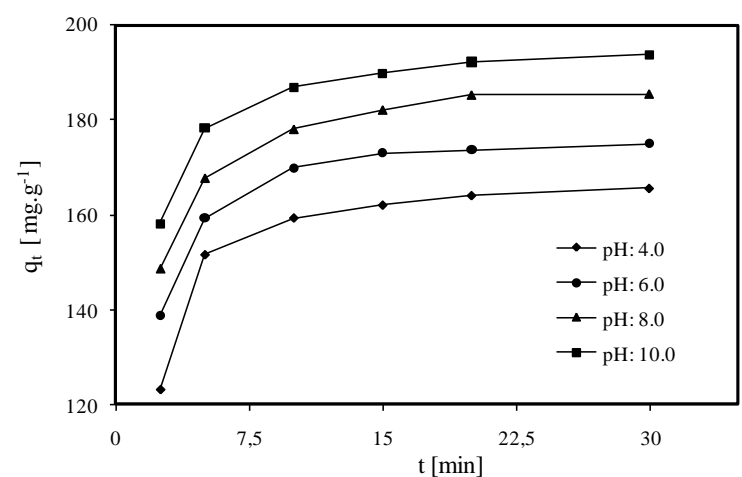

Figure 8. Effect of solution $\mathrm{pH}$ on dye adsorption on montmorillonite

(Conditions: initial dye concentration $100 \mathrm{mg} \mathrm{L}^{-1}$, adsorbent dosage $0.5 \mathrm{~g} \mathrm{~L}^{-1}$, temperature $293 \mathrm{~K}$, agitation speed $300 \mathrm{rpm}$, ionic strength $0 \mathrm{~mol} \mathrm{~L}^{-1}$ $\mathrm{NaCl})$

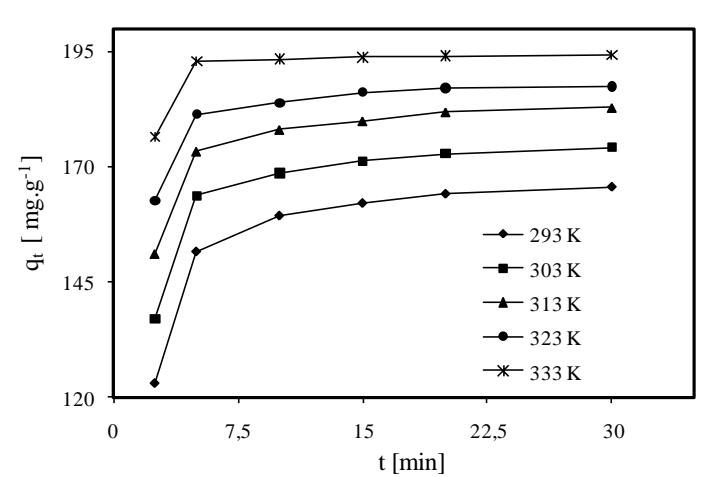

Figure 9. Effect of temperature on dye adsorption on montmorillonite (Conditions: initial dye concentration $100 \mathrm{mg} \mathrm{L}^{-1}$, adsorbent dosage $0.5 \mathrm{~g} \mathrm{~L}^{-1}$, agitation speed 300 rpm, ionic strength $0 \mathrm{~mol} \mathrm{~L}^{-1} \mathrm{NaCl}$, solution $\mathrm{pH}$ :

4.0)

\subsection{Activation parameters and thermodynamic parameters}

\subsubsection{Activation Energy}

Adsorption rate constant temperature dependence can be given as follows (Al-Ghouti et al., 2005):

$\ln k_{2}=\ln k_{0}-\frac{E_{a}}{R_{g}} \frac{1}{T}$

where $k_{2}$ is the pseudo-second-order constant $\left(\mathrm{g} \mathrm{mol}^{-1} \mathrm{~min}^{-1}\right), k_{0}$ is the rate constant of adsorption $\left(\mathrm{g} \mathrm{mol}^{-1} \mathrm{~min}^{-1}\right), E_{a}$ is activation energy of adsorption $\left(\mathrm{kJ} \mathrm{mol}^{-1}\right), R_{g}$ is the gas constant $\left(8.314 \mathrm{~J} \mathrm{~mol}^{-1} \mathrm{~K}^{-1}\right), T$ is the solution temperature $(\mathrm{K})$. Plotting of $\ln \mathrm{K}_{2}$ against the reciprocal temperature gives a reasonably straight line, the gradient of which is $-E_{a} / R_{g}$. From Eq. (12), the activation energy, $E_{a}$, is $27.635 \mathrm{~kJ} \mathrm{~mol}^{-1}$ (Fig. 10). The magnitude of activation energy gives an idea about the type of adsorption which is mainly physical or chemical. Low activation energies (5$50 \mathrm{~kJ} \mathrm{~mol}^{-1}$ ) are characteristics for physical adsorption, while higher activation energies (60$800 \mathrm{~kJ} \mathrm{~mol}^{-1}$ ) suggest chemical adsorption (Nollet et al., 2003).

\subsubsection{Thermodynamic parameters}

Free energy $\left(\Delta G^{*}\right)$, enthalpy $\left(\Delta H^{*}\right)$ and entropy $\left(\Delta S^{*}\right)$ of activation can be calculated by Eyring equation (Laidler and Meiser, 1999):

$$
\ln \left(\frac{k_{2}}{T}\right)=\left[\left(\frac{k_{b}}{h}\right)+\frac{\Delta S *}{R_{g}}\right]-\frac{\Delta H^{*}}{R_{g}} \frac{1}{T}
$$

where $k_{\mathrm{b}}$ and $h$ are Boltzmann's and Planck's constants, respectively. According to Eq. (13), a plot of $\ln (k / T)$ versus $1 / T$ should be a straight line with a slope $\Delta H^{*} / R_{g}$ and intercept $\left[\ln \left(k_{b} / h\right)+\Delta S^{*} / R_{g}\right] . \Delta H^{*}$ and $\Delta S^{*}$ were calculated from slope and intercept of line, respectively (Fig. 11). Gibbs energy of activation may be written in terms of entropy and enthalpy of activation:

$\Delta G^{*}=\Delta H^{*}-T . \Delta S^{*}$

$\Delta G^{*}$ was calculated at $293 \mathrm{~K}$ from Eq. (14). It is found that the values of the free energy $\left(\Delta G^{*}\right)$, enthalpy $\left(\Delta H^{*}\right)$ and entropy $\left(\Delta S^{*}\right)$ of activation is $51.412 \mathrm{~kJ} \mathrm{~mol}^{-1}, 25.041 \mathrm{~kJ} \mathrm{~mol}^{-1}$ and -0.090 $\mathrm{J} \mathrm{mol}^{-1} \mathrm{~K}^{-1}$, respectively. The free energy of activation, $\Delta G^{*}$ have also been computed at $293 \mathrm{~K}$ (Table 6).

Thermodynamical parameters were evaluated for BR 18 ions and showed that the adsorption of the dye is endothermic in nature. The positive value of $\Delta H^{*}$ showed that adsorption was favorable at higher temperature and the presence of possible chemisorptions phenomenon. The positive values of the Gibbs free energy change $\left(\Delta G^{*}\right)$ confirm that the adsorption process was not spontaneous 
whereas the negative values of the entropy $\left(\Delta S^{*}\right)$ confirm that the decreased randomness at the solid-solute during adsorption process.

Table 6. Thermodynamic parameters of basic red 18 adsorption onto montmorillonite

\begin{tabular}{|c|c|c|c|c|c|}
\hline & \multicolumn{5}{|c|}{$\mathrm{T}(\mathrm{K})$} \\
\hline & 293 & 303 & 313 & 323 & 333 \\
\hline$\Delta \mathrm{G}^{*}\left(\mathrm{~kJ} \mathrm{~mol}^{-1}\right)$ & 51.412 & 52.312 & 53.212 & 54.112 & 55.012 \\
\hline$\Delta \mathrm{H}^{*}\left(\mathrm{~kJ} \mathrm{~mol}^{-1}\right)$ & & & 25.041 & & \\
\hline$\Delta \mathrm{S}^{*}\left(\mathrm{~kJ} \mathrm{~mol}^{-1} \mathrm{~K}^{-1}\right)$ & & & -0.0900 & & \\
\hline
\end{tabular}

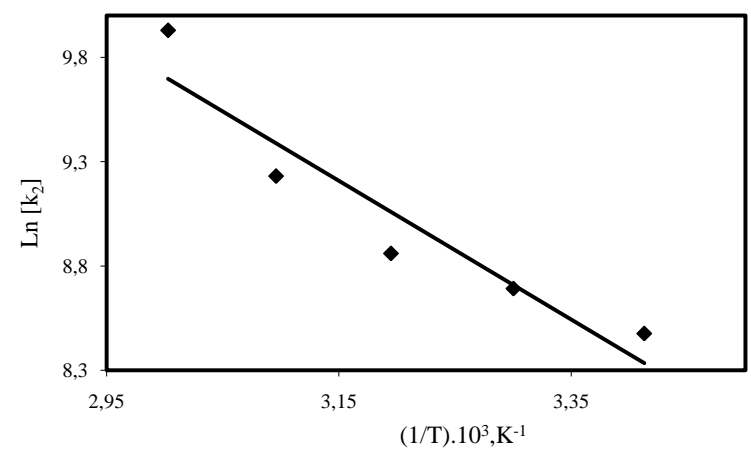

Figure 10. Arrhenius plots for adsorption of dye on montmorillonite

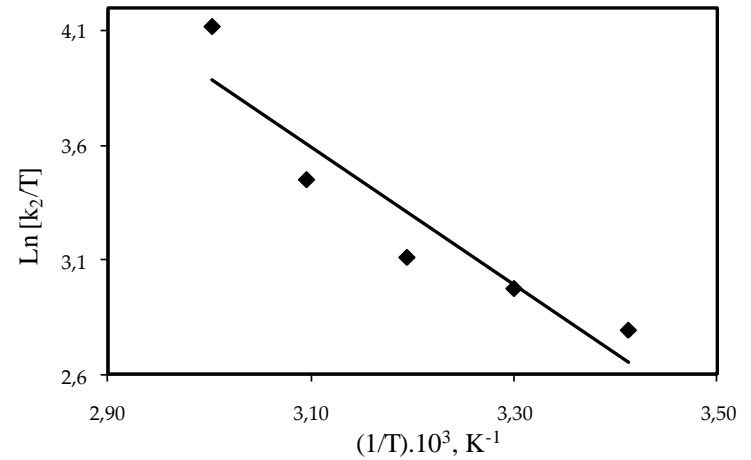

Figure 11. Plots of $\ln \left(k_{2} / T\right)$ versus $1 / T$ for adsorption of dye on montmorillonite

\subsection{Semi-empirical model for adsorption of BR 18 onto montmorillonite}

Adsorption capacity data obtained by a mass balance equation obeyed the pseudo-second-order equation, and selected parameters were effective onto the adsorption capacity and rate. Hence, based on Eq. (9), an semi-empirical kinetic model including effects of initial dye concentration, solution $\mathrm{pH}$, agitation speed, adsorbent dosage, ionic strength, temperature, and contact time was developed using 162 items of experimentally obtained results by means of Statistica 6.0 programme and given as follows:

$$
\frac{t}{q_{t}}=1.782 \times\left[H^{+}\right]^{0.0112} \times(A S)^{-0.1708} \times(A D)^{0.6858} \times[I]^{1.43 E-7} \times\left[C_{0}\right]^{-0.8668} \times \exp \left(\frac{4.267}{T}\right) \times t^{0.9495}
$$

where $\left[H^{+}\right]$is hydrogen ions concentration $\left(\mathrm{mol} \mathrm{L}^{-1}\right),(A S)$ is agitation speed (rpm), (AD) is the adsorbent dosage $\left(\mathrm{g} \mathrm{L}^{-1}\right),[]$ is $\mathrm{NaCl}$ concentration $\left(\mathrm{mol} \mathrm{L}^{-1}\right), C_{0}$ is the initial dye concentration $\left(\mathrm{mg} \mathrm{L}^{-1}\right)$, $T$ is the reaction temperature $(\mathrm{K})$, and $t$ is the contact time $(\min )$. The correlation between experimentally obtained $\left(t / q_{t}\right)$ and predicted $\left(t / q_{t}\right)$ was given in Fig. 12 .

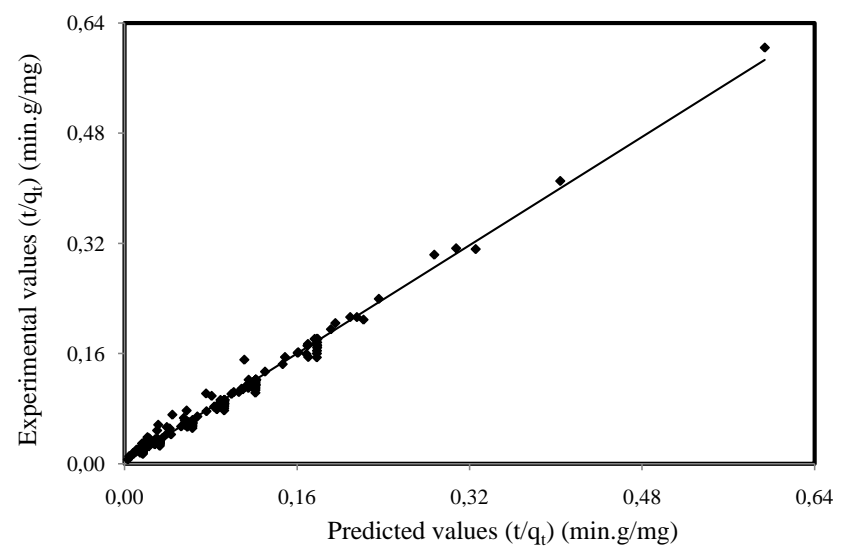

Figure 12. Correlation between experimental and statistically predicted $t / q_{t}$ values 


\section{CONCLUSIONS}

The results of this investigation showed that Turkish clay montmorillonite has a suitable adsorption capacity for the removal of BR 18 from aqueous solutions. The experimental results were fitted well with Freundlich isotherm model. The data indicate that the adsorption kinetics follow the pseudosecond-order rate with intraparticle diffusion as one of the rate determining steps. Adsorption capacity increased that with increasing $\mathrm{pH}$, temperature, agitation speed, initial dye concentration and ionic strength but, decreased that with increasing adsorbent dosage in spite of the increase percent removal. The activation parameters of the adsorption process helped in predication of how the adsorption of dye molecules might vary with temperature changes. The present study concludes that the montmorillonite could be employed as low-cost adsorbents as alternatives to commercial activated carbon for the removal of color and dyes from wastewater.

\section{REFERENCES}

Ahmad A.L., Loh M.M. and Aziz J.A., (2007), Preparation and characterization of activated carbon from oil palm wood and its evaluation on Methylene blue adsorption, Dyes and Pigments, 75, 263-272.

Akkaya G., Uzun I. and Güzel F., (2007), Kinetics of the adsorption of reactive dyes by chitin, Dyes and Pigments, 73, 168-177.

Al-Ghouti M., Khraisheh M.a.M., Ahmad M.N.M. and Allen S., (2005), Thermodynamic behaviour and the effect of temperature on the removal of dyes from aqueous solution using modified diatomite: $A$ kinetic study, Journal of Colloid and Interface Science, 287, 6-13.

Al-Ghouti M.A., Khraisheh M.A., Ahmad M.N. and Allen S., (2009), Adsorption behaviour of methylene blue onto Jordanian diatomite: a kinetic study, Journal of Hazardous Materials, 165, 589-598.

Allen S.J., Mckay G. and Porter J.F., (2004), Adsorption isotherm models for basic dye adsorption by peat in single and binary component systems Journal of Colloid and Interface Science, 280, 322-333.

Dogan M., Karaoglu M.H. and Alkan M., (2009), Adsorption kinetics of maxilon yellow 4GL and maxilon red GRL dyes on kaolinite, Journal of Hazardous Materials, 165, 1142-1151.

Dogan M., Özdemir Y. and Alkan M., (2007), Adsorption kinetics and mechanism of cationic methyl violet and methylene blue dyes onto sepiolite, Dyes and Pigments, 75, 701-713.

Doğan M. and Alkan M., (2003), Removal of methyl violet from aqueous solution by perlite, Journal of Colloid and Interface Science, 267, 32-41.

Doğan M., Alkan M., Demirbaş Ö., Özdemir Y. and Özmetin C., (2006), Adsorption kinetics of maxilon blue GRL onto sepiolite from aqueous solutions, Chemical Engineering Journal, 124, 89-101.

Dubinin M.M. and Radushkevich L.V., (1947), Equation of the characteristic curve of activated charcoal, Proceedings of the Academy of Sciences, Physical Chemistry Section, U.S.S. R., 55, 331-333.

El-Halwany M.M., (2010), Study of adsorption isotherms and kinetic models for Methylene Blue adsorption on activated carbon developed from Egyptian rice hull (Part II), Desalination, 250, 208-213.

El-Maghraby A. and El Deeb H.A., (2011), Removal of a Basic Dye from Aqueous Solution by Adsorption Using Rice Hulls, Global NEST Journal, 13, 90-98.

Elaziouti A. and Laouedj N., (2011), Effects of pH and Temperature on the Adsorption of Cationic Dyes from Aqueous Suspension by Maghnia Montmorillonite, Journal of the Korean Chemical Society, 55, 208-217.

Elovich S.Y. and Larionov O.G., (1962), Theory of adsorption from solutions of non electrolytes on solid (I) equation adsorption from solutions and the analysis of its simplest form, (II) verification of the equation of adsorption isotherm from solutions, Translated from Izvestiya Akademii Nauk SSSR, Otdelenie Khimicheskikh Nauk, 2, 209-216.

Fil B.A. (2007) The Investigation of the Use of Montmorillonite in the Removal of Methylene Blue, a Textile Dye, In: Institute of Science, Department of Environmental Engineering. Balikesir University, Balikesir.

Fil B.A. and Özmetin C., (2012), Adsorption of Cationic Dye from Aqueous Solution by Clay as an Adsorbent: Thermodynamic and Kinetic Studies, Journal of the Chemical Society of Pakistan, 34, 896-906.

Fil B.A., Özmetin C. and Korkmaz M., (2012), Cationic Dye (Methylene Blue) Removal from Aqueous Solution by Montmorillonite, Bulletin of the Korean Chemical Society, 33, 3184-3190.

Filipkowska U., Klimiuk E., Grabowski S. and Siedlecka E., (2002), Adsorption of Reactive Dyes by Modified Chitin from Aqueous Solutions, Polish Journal of Environmental Studies, 11, 315-323. 
Freundlich H.M.F., (1906), Over the adsorption in solution, The Journal of Physical Chemistry, 57, 385471.

Furusawa T. and Smith J. M., (1974), Intraparticle mass transport in slurries by dynamic adsorption studies,. Aiche Journal, 20, 88-93.

Ghazi I.E., Elamrani M.K. and Mansour M., (2003), Photocatalytic oxidation of the textile dye basic red 18 with irradiated titanium dioxide, Toxicological and Environmental Chemistry, 85, 1-6.

Guiza S., Bagane M., Al-Soudani A.H. and Amore H.B., (2004), Adsorption of basic dyes onto natural clay, Adsorption Science and Technology, 22, 245-256.

Ho Y.S. and Mckay G., (1998), A comparison of chemisorption kinetic models applied to pollutant removal on various sorbents, Trans Institution of Chemical Engineers, 76B, 332-340.

Ho Y.S., Wase D.a.J. and Forster C.F., (1996), Removal of lead ions from aqueous solution using sphagnum moss peat as adsorbent, Water South Africa, 22, 219-224.

lyim T.B. and Güçlü G., (2009), Removal of basic dyes from aqueous solutions using natural clay, Desalination, 249, 1377-1379.

Jain S. and Jayaram R.V., (2010), Removal of basic dyes from aqueous solution by low-cost adsorbent: Wood apple shell (Feronia acidissima), Desalination, 250, 921-927.

Jiang Y.-X., Xu H.-J., Liang D.-W. and Tong Z.-F., (2008), Adsorption of Basic Violet 14 from aqueous solution on bentonite, Comptes Rendus Chimie, 11, 125-129.

Karadag D., Akgul E., Tok S., Erturk F., Kaya M.A. and Turan M., (2007), Basic and Reactive Dye Removal Using Natural and Modified Zeolites, Journal of Chemical and Engineering Data, 52, 2436-2441.

Karim A.B., Mounir B., Hachkar M., Bakasse M. and Yaacoubi A., (2009), Removal of Basic Red 46 dye from aqueous solution by adsorption onto Moroccan clay, Journal of Hazardous Materials, 168, 304-309.

Karim A.B., Mounir B., Hachkar M., Bakasse M. and Yaacoubi A., (2010), Removal of basic dye "methylene blue" in aqueous solution by Safi clay, Revue des Sciences de l'Eau, 23, 375-388.

Kilic M., Apaydin-Varol E. and Putun A.E., (2011), Adsorptive removal of phenol from aqueous solutions on activated carbon prepared from tobacco residues: equilibrium, kinetics and thermodynamics, ournal of Hazardous Materials, 189, 397-403.

Kuleyin A. and Aydin F., (2011), Removal of reactive textile dyes (Remazol Brillant Blue R and Remazol Yellow) by surfactant-modified natural zeolite, Environmental Progress and Sustainable Energy, 30, 141-151.

Kumar P., Ramalingam S. and Sathishkumar K., (2011), Removal of methylene blue dye from aqueous solution by activated carbon prepared from cashew nut shell as a new low-cost adsorbent, Korean Journal of Chemical Engineering, 28, 149-155.

Kumar P.S., Ramalingam S., Senthamarai C., Niranjanaa M., Vijayalakshmi P. and Sivanesan S., (2010), Adsorption of dye from aqueous solution by cashew nut shell: Studies on equilibrium isotherm, kinetics and thermodynamics of interactions, Desalination, 261, 52-60.

Laidler K. and Meiser J.H., (1999), Physical Chemistry, Houghton Mifflin New York, 852.

Langmuir I., (1918), The adsorption of gases on plane surfaces of glass, mica and platinum, Journal of the American Chemical Society, 1361-1403.

Mane V.S., Deo Mall I. and Chandra Srivastava V., (2007), Kinetic and equilibrium isotherm studies for the adsorptive removal of Brilliant Green dye from aqueous solution by rice husk ash, Journal of Environmental Management, 84, 390-400.

Mckay G., Ho Y.S. and Ng J.C.Y., (1999), Bisorption of copper from waste waters: a review, Separation and Purification Methods, 28, 87-125.

Nandi B.K., Goswami A. and Purkait M.K., (2009), Adsorption characteristics of brilliant green dye on kaolin, Journal of Hazardous Materials, 161, 387-395.

Nollet H., Roels M., Lutgen,P., Van Der Meeren P. and Verstraete W., (2003), Removal of PCBs from wastewater using fly ash, Chemosphere, 53, 655-665.

Nuithitikul K., Srikhun S. and Hirunpraditkoon S., (2010), Kinetics and equilibrium adsorption of Basic Green 4 dye on activated carbon derived from durian peel: Effects of pyrolysis and post-treatment conditions, Journal of the Taiwan Institute of Chemical Engineers, 41, 591-598.

Özdemir Y., Doğan M. and Alkan M., (2006), Adsorption of cationic dyes from aqueous solutions by sepiolite, Microporous and Mesoporous Materials, 96, 419-427.

Pentrák M., Czímerová A., Madejová J. and Komadel P., (2012), Changes in layer charge of clay minerals upon acid treatment as obtained from their interactions with methylene blue, Applied Clay Science, 55, 100-107. 
Rafatullah M., Sulaiman O., Hashim R. and Ahmad A., (2010), Adsorption of methylene blue on low-cost adsorbents: A review, Journal of Hazardous Materials, 177, 70-80.

Rodríguez A., García J., Ovejero G. and Mestanza M., (2009), Adsorption of anionic and cationic dyes on activated carbon from aqueous solutions: Equilibrium and kinetics, Journal of Hazardous Materials, 172, 1311-1320.

Saltabaş Ö., Teker M. and Konuk Z., (2012), Biosorption of Cationic Dyes from Aqueous Solution by Water Hyacinth Roots, Global NEST Journal, 14, 24-31.

Sousa J., Freitas O.M. and Figueıredo S.A., (2012), Basic Dyestuffs Removal from Textile Effluents Using Feathers: Equilibrium, Kinetic and Column Studies, Global NEST Journal,, 14, 100-107.

Tahir S.S. and Rauf N., (2006), Removal of a cationic dye from aqueous solutions by adsorption onto bentonite clay, Chemosphere, 63, 1842-1848.

Temkin M. I., (1941), Adsorption equilibrium and the kinetics of processes on non-homogeneous surfaces and in the interaction between adsorbed molecules, Zhurnal Fizicheskoi Khimii, 15, 296-332.

Tsai W.-T., Hsu H.-C., Su T.-Y., Lin K.-Y., Lin C.-M. and Dai T.-H., (2007), The adsorption of cationic dye from aqueous solution onto acid-activated andesite, Journal of Hazardous Materials, 147, 10561062.

Unuabonah E.I., Adebowale K.O. and Dawodu F.A., (2008), Equilibrium, kinetic and sorber design studies on the adsorption of Aniline blue dye by sodium tetraborate-modified Kaolinite clay adsorbent, Journal of Hazardous Materials, 157, 397-409.

Varlikli C., Bekiari V., Kus M., Boduroglu N., Oner I., Lianos P., Lyberatos G. and Icli S., (2009), Adsorption of dyes on Sahara desert sand, Journal of Hazardous Materials, 170, $27-34$.

Verma V.K. and Mishra A.K., (2010), Kinetic and Isotherm Modeling of Adsorption of Dyes onto Rice Husk Carbon, Global NEST Journal, 12, 190-196.

Vimonses V., Lei S., Jin B., Chow C.W.K. and Saint C., (2009), Kinetic study and equilibrium isotherm analysis of Congo Red adsorption by clay materials, Chemical Engineering Journal, 148, 354364.

Wang X.S. and Zhang W., (2011), Removal of Basic Dye Crystal Violet from Aqueous Solution by Cu(II)Loaded Montmorillonite, Separation Science and Technology, 46, 656-663.

Weng C.-H. and Pan Y.-F., (2006), Adsorption characteristics of methylene blue from aqueous solution by sludge ash, Colloids and Surfaces A: Physicochemical and Engineering Aspects, 274, 154-162.

Weng C.-H. and Pan Y.-F., (2007), Adsorption of a cationic dye (methylene blue) onto spent activated clay, Journal of Hazardous Materials, 144, 355-362.

Wu F.-C., Tseng R.-L. and Juang R.-S., (2009), Initial behavior of intraparticle diffusion model used in the description of adsorption kinetics, Chemical Engineering Journal, 153, 1-8.

Yavuz Ö. and Aydin A.H., (2006), Removal of Direct Dyes from Aqueous Solution Using Various Adsorbents, Polish Journal of Environmental Studies, 15, 155-161.

Zohra B., Aicha K., Fatima S., Nourredine B. and Zoubir D., (2008), Adsorption of Direct Red 2 on bentonite modified by cetyltrimethylammonium bromide, Chemical Engineering Journal, 136, 295305. 